\title{
SARA PIWOWARSKA
}

Uniwersytet Śląski w Katowicach

ORCID ID: https://orcid.org/0000-0002-6925-8160

\section{Azja z zupełnie nowej perspektywy \\ [recenzja książki Spojrzenie na Azję] \\ Asia from a completely new perspective}

[book review Spojrzenie na Azję]

\section{Азия с совершенно новой точки зрения}

[рецензия книги Spojrzenie na Azję]

\begin{abstract}
Aja zajmuje kluczowe miejsce na geopolitycznej mapie świata. Ścierają się tam interesy zarówno Stanów Zjednoczonych, jak i mocarstw regionalnych, jak Chiny czy Japonia. Przemiany w Azji i pozycja tego regionu na arenie międzynarodowej wymagają interdyscyplinarnej analizy. Wydana w 2018 roku publikacja Spojrzenie na Azję, zawierająca wnioski z Międzynarodowego Kongresu Azjatyckiego, stanowi zupełnie nowe podejście do opisywania Azji i analizuje ten region na wielu różnych płaszczyznach.

Książka składa się z dwunastu rozdziałów, zawiera również wstęp, wprowadzający czytelnika w analizowaną problematykę. Duże zróżnicowanie tematyki poszczególnych artykułów pozwala czytelnikowi spojrzeć na omawiane zagadnienie $\mathrm{z}$ wielu perspektyw.

Pierwszy artykuł,„Azja jako współczesne centrum i peryferie”, autorstwa Macieja Szczurowskiego, podejmuje analizę koncepcji centrum i peryferii. Autor opisuje, jak mapa azjatyckich centrów i peryferii zmieniała się
\end{abstract}


w wymiarze historycznym oraz na ile Azja i poszczególne leżące na tym kontynencie państwa spełniają współczesne kryteria centrów lub peryferii. Artykuł opisuje również rolę, jaką spełnia Azja na arenie międzynarodowej, chociażby poprzez działalność organizacji międzynarodowych, takich jak Szanghajska Organizacja W spółpracy czy ASEAN (Stowarzyszenie Narodów Azji Południowo-Wschodniej).

Kolejny artykuł, „Chiny w dziennikach Józefa Kowalewskiego (18011878)", którego autorką jest Maria Magdalena Sztuka, opisuje wizję Chin w relacjach Józefa Kowalewskiego, mongolisty i orientalisty, który w latach 1830-1831 przebywał w Pekinie. Autorka opisuje historię życia polskiego orientalisty, głównie jednak skupia się na jego pobycie w Chinach, podejściu do tego kraju i jego mieszkańców. Artykuł opisuje także kontrasty pomiędzy obserwacjami Józefa Kowalewskiego, a tym, co ówcześnie myślano w Europie o organizacji państwa chińskiego, rozwoju medycyny czy oświaty w Chinach.

Artykuł Luizy Kliczkowskiej, „Przełomowy 1873 r. - nowe państwo, nowe prawo" opisuje zmiany, jakie wprowadzono w Japonii w 1873 roku. Autorka analizuje przyczyny, dla których ten rok uznaje się za przełomowy w historii Japonii. Przedstawia wydarzenia, które doprowadziły do likwidacji systemu feudalnego, a także przemiany w pierwszej dekadzie epoki Meiji, które sprawiły, że Japonia stała się nowoczesnym państwem prawa, inspirowanym kodyfikacjami prawa Zachodu.

Artykuł „Polacy w Japonii w okresie międzywojennym”, którego autorami są Katarzyna Amrozy i Bolesław Sprengel, przedstawia sylwetki Polaków przebywających w Japonii w okresie międzywojennym. Autorzy dzielą Polaków w Japonii na kilka kategorii: migrantów i osadników, dyplomatów, podróżników, naukowców i artystów oraz duchownych. Wśród sylwetek Polaków przedstawionych w artykule znajdują się m.in.: Józef Targowski, pierwszy oficjalny polski przedstawiciel, Henryk Zaniewski, Stefania Sempołowska, ojciec Maksymilian Kolbe oraz wielu innych.

Kolejny z artykułów, „Maoizm we Francji i pojęcie sprawiedliwości ludowej”, autorstwa Bartosza Płotki, przedstawia zjawisko sprawiedliwości ludowej i opisuje, jak wydarzenia mające miejsce we Francji w 1968 roku, związane z tzw. rewolucją kulturową, wpłynęły na ewolucję sprawiedliwości ludowej. Autor prezentuje również rolę Michela Foucaulta, wybitnego 
francuskiego intelektualisty, zafascynowanego maoistyczną ideą spontanizmu i odejścia od represyjnych instytucji państwowych.

„Obrona przez kulturę - przyczynek do analizy zakresu stosowania strategii w społeczeństwie wielokulturowym”, autorstwa Wojciecha Jarczyka, to analiza zakresu podmiotowego i przedmiotowego zastosowania strategii obrony przez kulturę. Autor wprowadza czytelnika w pojęcie obrony przez kulturę, opisuje jej rolę w łagodzeniu konfliktów wynikających $\mathrm{z}$ funkcjonowania w społeczeństwie wielokulturowym. Artykuł przytacza również przykłady udanego i nieudanego zastosowania strategii obrony przez kulturę, jak np. sprawa People vs. Moua, dotycząca młodego Laotańczyka, członka społeczności Hmongów, a także sprawa Bui vs. Alabama, dotycząca imigranta z Wietnamu. Autor przedstawia jak obrona przez kulturę uwzględnia osobiste cechy sprawcy czynu, przyczynia się do zachowania wartości ważnych dla mniejszości kulturowych. Poza zaletami tej strategii autor przedstawia również jej wady, a także kontrowersje związane z jej stosowaniem.

Artykuł Marii Lewandowskiej, „Analiza systemów medialnych Rosji i Chin" - perspektywa komparatystyczna, przedstawia zagadnienia teoretyczne związane $\mathrm{z}$ relacją systemu medialnego $\mathrm{z}$ systemem politycznym i modelami systemu medialnego, ponadto analizuje systemy medialne Rosji i Chin, a przede wszystkim dokonuje porównania tych systemów, skupiając się na poziomie interwencji państwa w system medialny, stopniu autonomii dziennikarskiej, czy wolności słowa.

Kolejny z artykułów, autorstwa Piotra Chodaka, zatytułowany jest Polski „Internet a Chiny na przykładnie CHINY to LUBIE”. Autor opisuje stworzonego przez siebie bloga CHINY to LUBIE, ukazuje trzy główne wizerunki Chin, funkcjonujące wśród polskich internautów: Chiny jako źródło wszelkiego zła, Chiny jako kraj przyszłości oraz Chiny jako upragniony orient. Celem artykułu jest zachęcenie do dalszej dyskusji nad Chinami w polskim Internecie.

„Buddyjskie korzenie myśli antynatalistycznej” - artykuł Bartosza Płotki przedstawia założenia myśli antynatalistycznej i zestawia je z założeniami buddyzmu. Autor rozważa czy myśl antynatalistyczna, która przypisuje narodzinom nowego życia negatywną wartość, obecnie - w obliczu wyzwań 
takich jak wzrost liczebności ludzi na świecie czy kończących się zasobów - może zyskać większe znaczenie.

Kolejny z artykułów, „, Tai Chi Chuan - sztuka walki i filozofowania”, autorstwa Adama Pawła Olechowskiego, opisuje historię, zasady, symbolikę, a także przedstawia zalety ćwiczenia Tai Chi Chuan. Autor przekonuje czytelnika, iż starochińska sztuka walki nie jest jedynie nastawiona na pokonanie przeciwnika. To nie tylko sport, ale również ćwiczenie duchowe pozwalające zajrzeć w głąb siebie, pogłębić znajomość chińskiej kultury oraz poprawić zdrowie fizyczne i psychiczne.

Artykuł „Krav maga jako element bezpieczeństwa indywidualnego”, którego autorką jest Katarzyna Amrozy, przedstawia izraelski system walki Krav magę. Autorka podkreśla, iż nie jest to sport walki ani sztuka walki, Krav maga nie jest bowiem nastawiona na współzawodnictwo, służy samoobronie. Ten system walki jest obowiązkowym elementem szkolenia izraelskich wojskowych, wywiadu czy policji. Autorka opisuje historię i zasady krav magi, przedstawia, jak wyglądają treningi. Przekonuje również, że krav maga kształtuje poczucie samokontroli, odpowiedzialności, uczy umiejętności działania w stresie.

Ostatni z artykułów tej publikacji nosi tytuł „Towarzystwo Świadomości Kryszny jako ruch społeczny w Polsce”. Autorka artykułu, Kamila Rezmer, przedstawia historię ruchu Hare Kryszna, jego cele i wartości. Autorka patrzy na ten ruch obiektywnie, $\mathrm{z}$ punktu widzenia politologa, charakteryzuje go nie jako ruch wyznaniowy, ale jako ruch społeczny.

Publikacja Spojrzenie na Azję może być dedykowana szerokiemu kręgowi odbiorców. Opublikowane w niej artykuły zostały napisane przejrzystym językiem. Książka stanowi zupełnie nowe spojrzenie na niezwykle istotny region, jakim jest Azja. Można w niej znaleźć informacje na temat różnych państw azjatyckich, kultur, wyznań, poruszone zostały także tematy związane z filozofią czy sportem. Publikacja ma charakter interdyscyplinarny, przybliża czytelnikom Azję i pozwala spojrzeć na ten kontynent przez pryzmat odczuć Europejczyków. 
MGR SARA PIWOWARSKA

Instytut Nauk Politycznych

Wydział Nauk Społecznych

Uniwersytet Śląski w Katowicach

ul. Bankowa 11, 40-007 Katowice

sara.piwowarska@wp.pl

\section{Bibliografia}

Marszałek-Kawa, J., Chałubińska-Jentkiewicz, K. (red.). (2018). Spojrzenia na Azję. Toruń: Wydawnictwo Adam Marszałek. 